\title{
Interventions on Europe's political futures
}

Keywords: Europe; borders; migration; international law; uneven development; power

Fiona McConnell

School of Geography and the Environment, University of Oxford

Merje Kuus

Department of Geography, University of British Columbia

Alex Jeffrey

Department of Geography, University of Cambridge

Heaven Crawley

Centre for Trust, Peace and Social Relations (CTPSR), Coventry University

Nick Vaughan-Williams

Department of Politics and International Studies

Adrian Smith

School of Geography, Queen Mary University of London

\section{Introduction}

Fiona McConnell

Europe is facing challenging times. The so-called 'migration crisis' has seen the hardening and militarisation of Europe's land and maritime borders. Terror attacks have scarred cities across the continent, and the far right is in ascendancy in France, Germany, the Netherlands, Austria and Hungary, amongst others. Nationalist politicians are framing European states as being under siege from Islamist terrorists and economic migrants, which has led to a rise in xenophobia and casual racism on the streets of European cities. Meanwhile the Euro-zone has seen a series of employment crises and economic bailouts. Alongside such political and economic turmoil, the European Union is facing unprecedented pressures. The 'Brexit' result of the UK's referendum on EU membership in June 2016 has led to profound uncertainty not only for the UK's relationship with Europe but also for the future of the Union itself (for analysis of Brexit see www.elsevier.com/connect/brexit-resource-centre). 
At the best of times Europe is a vast and unwieldy topic. As was the case 25 years ago another moment when a culmination of events warranted reflection on Europe's political futures - writing from the midst of geopolitical and geo-economic upheaval raises the challenge of how to gain perspective, to reflect on what is happening and to reassess how we approach issues. Yet as critical scholars it is imperative that we do so. In reflecting on the manifold challenges to the idea and space of Europe the interventions that follow are provocations: posing questions, unsettling taken for granted frameworks, and calling for new ways of thinking about and politically contributing to 'Europe'. Each author approaches Europe from a distinct perspective and offers a particular lens on contemporary European issues, bringing in ideas and framings from international relations, law, economic geography and migration studies. They also each draw on insights from their extensive empirical research in and on Europe. Cross-cutting the interventions are two calls to action: to rethink our analytical approaches to Europe, and to reframe our role as critical scholars.

The interventions make the case for a renewed analytical toolbox through a focus on three themes that have long animated political geography scholarship on Europe: borders, power and crises. The spatial politics of Europe is a topic that has consistently featured in the pages of this journal. Underpinning much of this work has been an interest in Europe's borders: their post-Cold War realignment, the differentiation between 'permeable' internal and 'fortress' external borders of the EU (Scott and van Houtum 2009; Carr 2012) and the Union's relationship with its neighbours (Bialasiewicz et al 2009; Petrakos et al 2016). The interventions by Smith and Vaughan-Williams speak to this work on Europe's borders, and, in drawing on the work of Balibar and Derrida respectively, do so in ways that bring to the fore vital questions of inclusion and exclusion, openness to the Other and violent closures. Vaughan-Williams calls for attention to be turned to the emergence of bordering practices that are enacted under the guise of humanitarian action in order to render 'irregular' populations 'knowable' and thus 'governable'. Meanwhile Smith argues that paying attention to borders as an intermingling of the geopolitical and geo-economic is crucial to mapping out emerging political geographies of difference, (uneven) development and power(lessness) in Europe today.

As illustrated by Smith's focus on inequality and marginalisation, the question of the nature of power in Europe runs through the interventions. Whilst much existing work has focused on the changing dynamics of EU 'soft' and 'civilian' power (Bachmann and Sidaway 2009; 
Clark and Jones 2008), Kuus argues that our conceptions of power are ill-suited for current political realities in Europe. In calling for more precision in our analytical categories she asserts we need to extricate ourselves from the national-territorial trap that has so dominated writing on Europe and instead demarcate trans-national regulatory power. Advocating a different shift in how we approach 'Europe’ Jeffrey argues that we should be less fixated on the meaning of Europe and turn critical attention to emphasising its use. In bringing to the fore questions of utility he sets Europe's political future alongside the future of international law, arguing that there is a mutually reinforcing functional and spatial relationship between them: addressing the future of European human rights law can provide leverage on the future modes of pan-European solidarity. Alongside borders and power, the interventions also turn critical attention to the notion of 'crisis', a term that has been widely discussed in the European context in recent years (e.g. Murphy 2013; Engelen et al 2011). Focusing specifically on the 'migration crisis', Crawley's intervention draws attention to the political agendas that produce the framing of recent events as crises, including ongoing geopolitical disputes (e.g. in the Aegean) and national politicians seeking to consolidate power and further domestic agendas. This raises the question of what value there is in the concept of 'crisis'. Crises prompt action, but in the context of the 'migrant crisis' the dominant mode of 'doing something' is politically problematic.

It is precisely the imperative of 'doing something' in response to the perfect storm of Brexit, growing inequalities and a shift to introverted, nationalist politics in Europe, that this set of interventions also addresses. Progressive academic voices and interventions are certainly needed, but at a juncture where expertise is viewed with suspicion at best and contempt at worst, how can critical geographers carve out a space to be heard? As noted above, one suggestion promoted in these interventions is to change our analytical framings and the questions that we ask. To what extent does the current disenchantment with the status quo and with the political establishment provide opportunities to think differently about the way politics works? What role can and should geographers play in fostering alternative geographical imaginations that push back against parochial nationalism? In critiquing the lack of concern with normativity in critical geopolitical scholarship, Jeffrey argues that we need to take bolder ethical, moral and political stances. On the one hand we need to be more direct in our writing: we need to describe state behaviour and political agendas as we see them, to call out injustices, xenophobia and discrimination. On the other hand we need to turn our empirical attention to overlooked stories of solidarity, compassion and inclusion that 
provide counter-narratives to dominant media and political discourses (see VaughanWilliams). Making connections - both conceptually and practically - between such movements, communities and actions has the potential to reimagine and enact a more progressive, open and inclusive Europe. With 2017 bringing the UK's withdrawal from the EU and elections in three of the six founder members of the European project (France, Germany and The Netherlands, each of which has populist Eurosceptic contenders), the need for such positive action could not be more timely.

\section{Locating Europe's power, or the difference between passports and passporting} Merje Kuus

The stories we tell about Europe are only as insightful as the analytical tools that underpin them. Much of what is said about politics and identity in today's Europe is too general: it tells a catchy story with lots of villains, but it is largely a familiar story of national competition and national identity. In an effort to be more precise about our analytical categories, I probe the customary meanings of Europe and power in today's Europe. I underscore the insidious ways in which the conventional wisdom channels our thinking into a nation-based frame of power. The intervention consists of three points: the first concerns Europe, the second concerns power, and the third concerns our analysis of regulatory power. All draw on geographical research and my own study of European Union (EU) decision-making (Kuus 2014).

'Will there still be Europe next year?' is the kind of small-talk query I have received for years now. 'Why not?' has become my stock answer. 'Where would the world's largest economy go?’ My interlocutor may well cover up some discomfort at that point, as they associate Europe with economic troubles, not power, even when standing in a queue for EU passports. Although Brexit will take off over two trillion dollars from the union's Gross Domestic Product, I expect to continue confounding small-talk with some similar statisticfor mainstream media reports would lead one to believe that Europe is down the drain without the Brits. The widespread ignorance about the union's regulatory power-ignorance that pre-dates the Grexit, Dexit, or Brexit rhetoric by many years—is instructive of a broader blind spot in our political and geographical imagination. 
Academics certainly know that the EU is a powerful trade bloc, but they too habitually discuss economic power in national terms. Although a consumer product in Europe is effectively governed by EU-wide standards-which contain heavy doses of governmental and private sector lobbying, are transposed into national law, and are implemented largely by national agencies - the popular image of that product remains wedded to nation-states. We view a Volkswagen car as a German rather than European product. EU regulatory power, and regulatory power more broadly, remains largely out of view. There are no catchy logos for it. EU power is abstract even for the professionals tasked to advance it. In my work on diplomacy, representatives of EU routinely mention that national diplomats are 'astonishingly' ignorant of what their EU counterparts actually do. An interviewee puts the difference between national and EU diplomats this way: 'An ambassador promotes trade; an EU ambassador creates the conditions in which trade can flourish'. Trade can be measured: how many products 'made in France' enter Canada in a given year can be calculated. The regulatory processes that enable trade: the nitty-gritty around the labelling of cheeses, the functioning of electronic borders, or the rules of public procurement, is boring technical stuff. The slow and never-ending negotiation and coordination of national positions happens out of view because national audiences are not keen to know it happens. Compromise-making tends to be hidden from domestic audiences in any event, another interviewee remarks drily: most societies do not want compromise because it destabilizes the national grand narrative. The upshot is that EU power is treated as a veneer on an otherwise national picture. This obscures the parallel process: the ways in which national labels serve as a veneer on EU regulations. The analytical task is not to sort out where the nation-state ends and the EU begins, but to grasp that Europe and its member states are not distinct practically or analytically. Although EU regulations present themselves to the observer in national form, they are transnational rather than national in content and origin.

Europe's power is obscure in part because our analytical toolbox makes it such. The problem is not only that EU has not yet acquired sufficient amounts of 'real' power but that our conceptions of power and ways to assess it (through statistics, for example) are ill-suited for political realities there. When people say that the EU is not a strong power or it is becoming a stronger one, they tacitly frame power in national and realist terms. When they say that the union is finally 'growing up' as a global power, they mean that it is becoming more state-like. The assumption holds in Brussels as well as national capitals. When EU officials sigh for a stronger union, they typically wish to see a more state-like actor: more coherent, focused, and 
self-assured, with its own (and nobody else's) institutions, elites, and regulatory space. That the EU can never achieve: its institutions, spaces, and organizational cultures are necessarily entangled with multiple national ones. No state-like or pure EU spaces exist.

The union has not been able to craft a compelling narrative of itself in part because its institutions pay deep deference to nation-states. In the short run, they are wise to do so given that these institutions depend on the member states. At the conferences and talks that touch on EU external relations, I regularly observe that the union's diplomats uphold not the EU but the member states. For a national diplomat, to not defend her state's policies is unthinkable. Yet EU diplomats routinely refrain from defending EU policies. They do so because every EU policy irritates at least some national capitals and most irritate many such capitals. There is indeed no Europe without nation-states, as EU officials swiftly point out. What they do not say is that there are no nation-states in Europe without the EU today. Effective state power requires the EU and this is why states invest in the union. Nation-states are integrally involved in all regulatory processes, but they are not in full control of these processes.

My conceptual claim is that our analyses of power are still laden with nation-envy. Catchy narratives on democracy, identity, and solidarity tend to take us back into the national matrix in more ways than first meets the eye. They tell us where power is and what it is in terms set by specifically modern discourses of spatiality and temporality' (Walker 2000: 14).

Regulatory space cannot be effectively analyzed by analytical tools that define power in territorial terms either by molding it into a patchwork of states of by scaling it up into Europe as a state-like structure (Bialasiewicz 2008). Without an explicit effort to be more precise about regulatory power academics too perpetuate the frame. They too do not yet have a terminology for the kind of imbrication and deliquescence of the national and the transnational that characterizes today's Europe. Nation-state and nationality consequently continue to function as placeholders in our 'metageographical understandings of political space’ (Murphy 2013: 719). The structure of the argument-where the narrative starts and ends - remains centered on national interests (see also Jones 2015). As a result, seemingly diverse arguments begin and end with the state. Although nationalism and the nation-state are omnipresent categories of practice in our world, they are not necessarily the appropriate categories of analyzing that world. 
The discussions around Brexit illustrate the point. The pre- and post-referendum rhetoric in both national and EU outlets has been overwhelmingly about the anticipated retreat of integration and the increase of national power. The EU loses and the member states gainnot that states become better off but that decision-making is further shifted from Brussels to national capitals. Yet the specific discussions around migration, banking, or trade agreements center on EU regulations and the instability that result from the renegotiation of these regulations. The frame of the discussion is largely national, but the substance of that same discussion is largely about transnational regulatory spaces. Consider, for example, passporting as distinct from passports. Much is written, in popular and academic outlets alike, about inter-state migration and national identity. Very little is said, outside specialist media, about the societal impact of passporting rights — the rights of third country companies that are registered in at least one member state of the European Economic Area to operate across the entire area. To highlight passporting is not to downplay the impact of migration or identity on people's lives, but to foreground the obscure yet consequential transnational standards that receive scant attention even in academic geography. Passports are tangible icons of nationality, whereas passporting is an intangible artefact of a transnational regulatory space.

Most academics perhaps agree that our analysis of Brexit cannot be only about states: it should also address banking regulations, class politics, regionalism, and so on. But how often is the sovereign debt crisis or the pan-European discontent over regional and class inequality discussed without implicitly locating these processes in states through the use of national statistics or the evocation of national perspectives? Academic analyses too focus customarily on the 'what' question: what the German Chancellor says or the London bond-traders or the Greek voters do. The 'where' is assumed: somewhere in the inter-state system. True, these processes cannot be discussed without the specific geographical contexts in which they occur. But these contexts cannot be explained by national labels. The territorial trap has received lucid critique theoretically (e.g. Reid-Henry et al., 2010) and there are now many insightful studies of the everyday constitution and transformation of state power. When it comes to today’s Europe though, the empirical analysis still tends to revert to the categories of Britain, France, Germany, and so on. In our discipline too, the habitual spatial labels easily obscure the transnational processes at hand. Berlin and London are not where they are supposed to be either. 
My argument is not about the evils of nationalism or the putative remedies to these evils from Brussels. That city is no less statist than national capitals. In Brussels too, and in some ways especially in Brussels, individuals and initiatives are obsessively fitted into the national matrix (Kuus 2016). My suggestion is not that we prioritize Europe over the nation-state but that we not reach for that distinction to analyze the world. The question is not about whether the politicians get the balance between national and EU power right or, as the right-wing movements would put it, whether the elites finally recognize the practical and moral centrality of national sovereignty in our world. Neither is the question about whether people across Europe are willing to rethink their attachment to national identity. The question is about how we locate and demarcate trans-national regulatory power.

\section{European Legal Geopolitics}

Alex Jeffrey

In this brief intervention I want to set Europe's political future alongside the future of another transnational entity: international law. Both these concepts - Europe and international law -are beguiling in their ambiguity, they both suffer from the same challenges that Philip Abrams (1988) identified when studying the state, that by using either as a starting point for discussion we grant singularity to what are, when scrutinised to any empirical extent, plural and dynamic. But their similarities extend beyond ambiguity, there is also a functional relationship between these two spatial ideas; Europe has been produced through international law while its enactment has transformed the institutions and norms through which law is understood and enshrined. As illustrated by debates encircling the EU Referendum in the UK, the establishment of Europe as a political entity has reorganised the geography of legal jurisdiction and accountability from the nation-state towards a transnational and cosmopolitan set of practices and attachments. Since the future of Europe is, then, interlinked with the future of international law we need a clear sense of the purpose and utility of international legal structures in defending rights and addressing misconduct.

In making these comments I want to invert Julia Kristeva’s (2000) familiar statement made in The Crisis of the European Subject that 'Europe must become not just useful, but also meaningful' (see Delanty and Rumford, 2005: 1). In thinking through international law and Europe together I am arguing here that perhaps as scholars we have often become rather 
fixated on the meaning of Europe and perhaps less articulate on emphasising its use. This fascination with meaning could be interpreted as another example of the rather weak concern with normativity within critical geopolitical scholarship, where the observation of plural meaning has stood in place of a defence of a particular ethical or moral pathway (Megoran, 2008). As an example, in previous work I have spent time thinking about the paradoxes that surround the interpretation of Europe within processes of the expansion of the European Union, where differently-positioned actors may simultaneously present Europe as both a cosmopolitan utopia and a defence of particular rigid cultural identities (Jeffrey, 2008). Perhaps like others I was founding such observations on assumption of ever expanding and deepening Europeanisation, thus defence of a particular interpretation of this process seemed neither relevant nor necessary. In stressing questions of utility, I want to focus on just three elements of this entwined question of Europe and international law: capacity, violence and agency, in each drawing on work I have been conducting examining the emergence and institutionalisation of mechanisms of transitional justice in South East Europe.

There are a series of general statements that may be made that point to common beginnings for both the normative ideal of Europe and the institutionalisation of international law. They have a similar moral origin point in confronting the excesses of state violence while enshrining the virtues (economic, political and legal) of transnational cooperation. The modern European project and the Nuremberg Trials were both products of the post-WWII political and legal settlements, one looking to foster future cooperation between states and harmonisation of legal norms; the other looking back to make examples of key individuals for atrocity crimes of such magnitude they required the constitution of an international tribunal.

It is tempting to go on to trace a timeline of historical developments in the institutionalisation of international law leading up to the International Criminal Court through the 1998 Rome Statute, but I want to highlight a different rebalancing of international law across the twentieth century, drawn out in the work of international lawyer William Schabas (2012), away from an emphasis on retributive forms of law that seek to try perpetrators for serious crimes, towards a defence of individual rights. This is perhaps best exemplified in the intersection of Europe and international law in the form of the European Convention on Human Rights (Drafted in 1950 by the then newly formed Council of Europe, the convention entered into force on 3 September 1953) and the European Court of Human Rights (21 January 1959 on the basis of Article 19 of the European Convention on Human Rights). 
But there are significant questions of capacity when we think of the operation of an institution such as the European Court of Human Rights (ECtHR). The expansion of the Council of Europe has expanded the number contracting states to the Convention to 47, covering a population of 800 million. There were 404 applications to the Court in 1981, by 2008 there were 49850 (Keller et al., 2010). Alongside issues of capacity are the issues of non-implementation of judgements -- that states whose constitution or laws are found to violate the Convention have found it too easy to simply ignore rulings and continue discriminatory practices. For example, since 2013, in the wake of the Sejdić and Finci case brought to challenge the constitutional arrangements on the Presidency of Bosnia and Herzegovina, the constitution of Bosnia and Herzegovina has been found to violate the human rights of its inhabitants by declaring that the President must self-identify as Serb, Croat or Bosniak. Despite this state of affairs, to date little has been done to reform the constitution. So while the ECtHR presents the opportunity for legal redress, it is bound by both resource constraints and the ultimate arbitration of the contracting states.

But alongside these issues of logistics within the ECtHR we also need to set place both Europe and international law within uneven landscapes of power. In a sense we need to sit the origin story set out above alongside a series of other geopolitical and historical narratives that illuminate different facets of both Europe and international law, in particular emphasising their violence. Firstly we realise that international law did not begin at Nuremburg and Europe did not spring into existence after World War II. This process requires provincializing both Europe and International Law, to use Chakrabarty's (2009) term, an action that challenges the triumphalist narrative of Europe as the origin point of modernity while destabilising a sense of international law as an unvariegated virtuous global enterprise. These assumptions are effects of power rather than empirical observations. When we engage in provincializing these concepts we see that they are, again, intertwined. European colonial practices of the $17^{\text {th }}$ to $20^{\text {th }}$ centuries were founded on an imagination of extra-local legal legitimacy, the crushing of customary forms of law and erasing many indigenous practices of international, transnational or regional legal cooperation that had thrived to this point. This provides a tangible account of the violence through which legal order is created and reproduced, as Comaroff and Comaroff (2006) make clear: law originates in violence and lives by violent means. In part this violence is avowedly symbolic, an ability 
to present itself and its operation as cold, rational judgement in the face of widespread injustice, oppression and marginalisation.

There are countless ways in which we could trace the violence of both European border making and the performance on international law, as the interventions here on the treatment of refugees and the securitisation of European borders attest. I want to draw these together through the increasing focus over the latter part of the $20^{\text {th }}$ century on the individual, partly a reflection of the growing reach of international legal institutions, partly the failure of states to enact legal protections and partly a reflection of growing neoliberal political economy emphasising the responsible subject. While this has provided opportunities for redress, it is also shifting responsibility for accessing the basic resources of life down to individuals without the ability to navigate complex legal systems. The expanding and deepening system of lawfare in both Europe and beyond - understood as the resort to legal instruments to pursue political ends - entrenches this potential inequality and violence (Jones, 2016).

But I want to end on a more hopeful note that points to the potential opportunities than that promoted by a more individualised account of law. In recent work examining processes of transitional justice in South East Europe I have examined countless instances where transnational legal authorities provided sites for redress (see Jeffrey and Jakala, 2015). For example, for those seeking compensation or legal recognition as a victim of war crime in Bosnia and Herzegovina the ECtHR provides a key institution through to either achieve a legal outcome - lay claim to the resources or title to which they are due - or simply to providing a moral framework against which the behaviour of other (national or local courts) may be brought to account. The existence of the ECtHR provides the means through which styles of multi-level citizenship may be performed, where state institutions in site like Bosnia are incapable or reluctant to pursue human rights abuses, the European court has a key role to play.

Though this could be interpreted as a simple re-scaling of judicial process, the research has found that the existence of the transnational court has performed a variety of (sometimes seemingly contradictory) outcomes: from rekindling a trust in legal processes, to encouraging activism against the absence of commemoration for atrocities of the past. Rather than a material resource, the value of the ECtHR stems from the more intangible set of "hermeneutic resources” (Boyle and Kobayashi, 2015: 711) produced through the operation 
of juridical processes. Not only does this point to a wider set of agencies beyond the narrow confines of legal action, it encourages reflection on the spatial and temporal understandings of the outcomes of law. Rather than thinking of legal outcomes across the spatiality of particular jurisdictions and the temporality of trial justice, this approach attempts to think through the common resources produced through law and the implications for understandings of justice and due process. In these terms, and returning to Kristeva, the meaning of Europe is a reflection of its use.

The geopolitics of the entanglement of Europe and international law is certainly complex and paradoxical, but our analysis must push for more. The future of European human rights law is not to view its inherent weaknesses or complexity as the grounds with withdrawal or parochialism, it is not to introduce 47 different state-level bills of rights. Rather it is one of illuminating the limits of law, of addressing its logistical challenges, in civil society, government and legal circles, to strengthen the forms of commonality and solidarity forged through transnational legal practices.

\section{'It's the politics, stupid': the use and abuse of migration to Europe Heaven Crawley}

Much has been said about the arrival of one million people on the shores of Southern Europe during the course of 2015. The vast majority - an estimated 850,000 (IOM 2016) -travelled in small, overloaded motorised rubber dinghies arriving on the Greek islands that lie just a few kilometres across the Aegean from the coast of Turkey, where than three million Syrian refugees, not to mention a host of refugees and migrants from other countries, have fled since 2011. The majority of those arriving have come to Europe in search of protection and an opportunity to rebuild their lives in the face of protracted conflict that has ripped apart their homes and families (European Commission 2016).

Whilst these numbers and the images with which they have come to be associated - of sinking boats, drowned children and families huddled in the mud - are striking and dramatic, the 'crisis' with which the movement of people to Europe came to be associated cannot, and should not, be attributed to numbers alone. As one of the richest regions of the world with a population in excess of 500 million across 28 Member States, the scale of the flow, 
representing as it does just $0.2 \%$ of the EU's population, is small relative to that of other countries. Around one and a half million refugees are currently living in Lebanon, a country half the size of Wales and with a population of around just over four million. Pakistan hosts more than three million refugees, mainly from Afghanistan. It has done so for decades (UNHCR 2015).

Moreover the escalation of people arriving into Europe in 2015 was utterly predictable (Spijkerboer 2016). Events associated with the Arab Spring in late 2010, the ousting of Muammar Gaddafi and deterioration of living and working conditions in Libya (particularly for Black Africans) the following year, and the Syrian civil war which has progressively escalated since March 2011, meant that the exodus of millions of people from the region was almost inevitable. In the longer term, shifting patterns of work and the opportunities associated with globalization and increased communications have revolutionized knowledge and perceptions of other parts of the world and accelerated access to information about how, and where, to travel in search of protection and the opportunity to (re)build a life (Collyer 2015; Thulin and Vilhelmson 2015).

Why then has increased migration to Europe been the source of such political and public anxiety, arguably bringing the European Union itself to the brink of collapse? Having recently completed a 12-month research project exploring the dynamics of migration across the Mediterranean during 2015', I have come to the conclusion that the so-called 'migration crisis' has far more to do with the current state of the European Union, established as a peace project to build political consensus in the aftermath of World War Two, than it does about the realities of contemporary migration. The 'crisis' is not a consequence of numbers per se but rather is symptomatic of wider geopolitical tensions and anxieties arising from profound and longstanding differences between EU Member States and across the wider European region. It is also a manifestation of a much broader and more complex debate about how international migration, in all its forms, impacts on European societies and economies (Geddes and Scholten 2016).

Of course the politics of migration to Europe are nothing new. Since the early 1990s scholars have highlighted the transformation of migration away from essentially an administrative issue of border management to one which in which mobile non-Western subjects are constructed as a form of deviance or even threat (Roger 1992; Huysmans 2000; Korkut et al 
(eds) 2013). But in 2016 the politics of migration took on a particularly toxic and explicit form as countries both inside and outside the European Union jostled for position, frequently using the movement of people to maintain or consolidate political power internally and in relation to one another. It is hard to summarise the depth and complexity of this process in this short intervention but two examples illustrate this point particularly clearly.

The first speaks to relationships between countries and specifically the geopolitics of the Aegean. It is not possible to understand why so many people were able to make the irregular crossing from Turkey to Greece without understanding the tense geopolitics and the complex and longstanding dispute over the Aegean Sea that dominate the relationship between the two countries (Vassalotti 2011). This relationship played out on a daily basis on its waters during the course of 2016.

\section{INSERT FIGURE 1 AROUND HERE}

Figure 1: The Turkish coastline, just 10km across the Aegean from the beach at Eftalou on the Greek island of Lesvos. Photo: author's own

The political geography of the region is characterized by islands in the eastern part: Chios, Lesvos, Iraklides, Rhodes, Samos, Kos and many others, which are very close to the Turkish coast but are Greek territory (Figure 1). The boundaries were established in accordance with the Treaty of Lausanne in 1923, which recognized the dissolution of the Ottoman Empire and established Turkey's current borders. Both nations disagree on the sovereignty of certain Greek islands, islets and even rocks, the continental shelf delimitation and the territorial sea breadth (Vassalotti 2011). In the early 1970s, Turkey initiated a systematic policy of claims against the sovereignty, sovereign rights and international responsibilities of Greece in maritime, island and air space. The advent of this new Turkish policy coincided with the Turkish invasion of Cyprus in July 1974 and subsequent occupation of the island's northern portion, which continues to this day, decisively impacting on relations between the two countries. Dealing with the movement of large numbers of people across the Aegean has been made all the more difficult given Greece and Turkey’s refusal to work together, a mutual animosity which stems from longstanding maritime territorial disputes and threat perceptions (Van Dyke 2005). During my time undertaking fieldwork on the Greek island of Lesvos the accounts I heard were not of collaboration between Greek and Turkish navy and coastguard 
vessels patrolling their territorial waters but of waterborne skirmishes and opportunistic land and sea grabs as each sought to claim or disclaim responsibility for rescuing those in distress, in turn claiming ownership of the Search and Rescue Region (SRR) in which they were located. The arrival of NATO ships in the Aegean, ostensibly to provide information and surveillance to counter human trafficking and criminal networks rather than to push back the boats to Turkey, added a further dimension to this already highly complex - and highly militarized - geopolitical context.

Turkey, meanwhile, frustrated by decades of what it perceives as deliberate stalling tactics on the part of dominant Member States to block its EU membership, very quickly came to realise that its geographical position as the gateway to Europe for the vast majority of refugees and migrants gave it the political bargaining power it had previously lacked. Standing on the beach at Eftalou and watching as Turkish coast guard boats encircled some dinghies causing them to sink whilst allowing others to cross provided a vivid and distressing insight into the ways in which the ebb and flow of departures from the Turkish coast was intended to 'send a message' to the EU that the flow could be controlled provided that the financial and political incentives were sufficiently high. This is the context within which the European Union agreed to give Turkey €6 billion to solve its 'migration crisis' (de Marailly and Garde 2016). Although the future of the agreement remains in doubt, Turkey insisted that discussions about a pathway towards EU membership were resumed and was also able to leverage early access to visa-free travel for Turkish citizens on the back of the deal.

The second example relates to the use - and abuse - of the 'crisis' by national politicians to leverage political and public support at the national level for their own domestic agendas and interests. Anti-migrant attitudes, racism, Islamophobia, and the direct linking of migration to issues of security and threats of terrorism, have marked not only public opinion in the countries of Europe but also the rhetoric of many of its political leaders.

In the summer of 2015, when the number of people arriving into Greece and travelling onwards to other parts of Europe through the Balkans started to significantly increase, the Hungarian Prime Minister, Viktor Orbán, wrote to every single citizen of Hungary and asked them to complete a questionnaire asking how they thought the government should respond to Europe’s ‘migration crisis’ (Hungarian Government 2015). Orban’s letter referred to the horror and bloodshed of the terrorist attack on the offices of Charlie Hebdo in Paris and 
directly linked this to the failure of the EU to control immigration. Claiming that those who present themselves as refugees are in fact illegal immigrants "coming to enjoy our welfare systems and the employment opportunities our countries have to offer”, Orban explicitly contrasted his stringent approach with what was described as the 'lenient policy' of Brussels. The findings of the survey, answered by nearly one million citizens, were subsequently used to legitimate a series of giant billboards intended to send a message to migrants to stay away or move on: ‘If you come to Hungary, you mustn’t take away Hungarians’ jobs’, 'If you come to Hungary, you must respect our culture', and 'You must abide by our laws' (see Figure 2). However, since few if any refugees and migrants actually understand Hungarian, these warnings were clearly intended to increase public anxiety and win support among citizens for planned anti-immigration laws and measures (Howden 2016). According to Schepelle (2015) the only political competition Orban faces comes from an even more farright opposition. In this context the aim was not simply to allow Hungary to evade its obligations under international and European law but to win political support at home by annoying Brussels.

\section{INSERT FIGURE 1 AROUND HERE}

Figure 2: Billboard posted by Hungary’s National Consultation on Immigration and Terrorism proclaiming 'If you come to Hungary, you must respect our culture!'

These examples reveal, as Merritt (2016) suggests, “a topsy-turvy world of prejudices, misunderstandings and sheer political opportunism”. Rather than engaging with the complex dynamics and drivers of migration across the Mediterranean in 2015 as revealed by our research (Crawley et al. 2016), the countries of the EU have used the issue of migration to consolidate their own political power and to challenge others. Much of what has been said and done in response to increased migration flows across the Mediterranean has not been focused primarily on addressing the underpinning drivers of migration, providing appropriate and timely humanitarian assistance or creating opportunities for integration but rather serves the purpose of positioning countries in relation to one another or of signalling to the domestic population that the government is 'standing up for' a particular country and 'protecting' its rights and interests. Seen from a geopolitical perspective it is also clear that the so-called 'crisis' is being used as a front to further other longer-term political agendas, most notably the pathway to EU accession for countries such as Turkey. 


\section{Of monstrous partitions and other shores: Europe's political futures through the lens of the border}

Nick Vaughan-Williams

Coventry city centre, UK, 21 May, 2016. 220 English Defence League supporters march from The Litten Tree pub to the city's Council House with banners reading: 'All entry to the UK determined by $100 \%$ laws enforced by $100 \%$ effective borders'; 'Refugees not welcome', and 'No Islam, no EU, Brexit'. A bewildered tourist comes up to me as the crowd moves past and says: 'What is this all about?'ii

Staderini Open Centre, Rome, 2 June, 2016. 'The smugglers brought us one cake per day, beat us, and forced us to drink diesel - it stops the hunger - and then we had to pay them $\$ 8000$ or give them our kidneys. We got on two boats - they made us pay $\$ 100$ for a life jacket, but then they took it away because there was not enough space. We got here two days ago, but the other boat sank. We've not been eating here, after fingerprint and medical test no one has asked us what we need, no one tells us what is happening, we are treated like animals; we were told Europe is better, but now we want to leave Italy. If I've survived the sea I deserve to live'.iii

Since the 'irregular' arrival in 2015 of more than one million migrants and refugees in Europe fleeing from violent conflict and poverty in Africa and the Middle East, border security has been catapulted to the top of the European Union (EU) Commission's strategic agenda. Although the securitization of migration and the militarisation of external border control have been a gradual process since the 1985 Schengen Agreement, these dynamics have intensified with the European Agenda on Migration, the Valletta Summit on Migration, and the EU Global Strategy. What is common to these and other high-profile policy responses is a renewed commitment to tougher border security as a deterrent against ‘irregular’ migration to Europe.

This emphasis on tougher border control has been justified by the EU Commission in the name of the safety and security of EU citizens - particularly in the aftermath of the Paris 
terror attacks in November 2015, the suicide bombing at Brussels airport in March 2016, and the violent incidents in Nice, Würzburg, Munich, and Ansbach in short succession in July 2016. In its Communication ‘Enhancing Security in a World of Mobility’ (EU Commission 2016), the Commission refers to a 'powerful consensus' among public opinion of the need to enhance EU border security measures. Eurobarometer surveys since 2015 do indeed depict a hardening of attitudes towards the issue of immigration and an emerging - or perhaps reemerging - culture of hostility, xenophobia, and racism across Europe. Negative public opinion towards immigration has been associated with a rise in anti-establishment populism and increased support for far-right groups: Germany’s PEGIDA and AFD, the Front National in France, the Swedish Democrats Party, and the English Defence League (EDL) have all targeted migrant and refugee communities and sought to resist what they consider to be weak border security measures on behalf of their respective states. Increasingly these views are no longer perceived to be confined to the far right, but have become normalised throughout mainstream European politics - as indicated by a majority of voters opting for 'Brexit' and to 'regain control of our borders' in the UK’s EU referendum in June 2016.

In order to begin to map and conceptualise these diverse political geographies of difference, power, and powerlessness in Europe today, I want to suggest that we would do well to return to the concept of the border. By this I not only mean the need for an even greater critical attentiveness to the changing nature, location, and impacts of attempts to control the mobility of some in order to secure the freedom of others at the level of EU policy-making. I also mean greater awareness and scrutiny of the ways in which bordering practices operate at the level of the everyday, permeate and structure local spaces, and are experienced physically and emotionally by those performatively produced as 'irregular' and 'regular' populations. Europe's political futures are being carved out in the here and the now - not only in Brussels, but also in everyday encounters between migratory and sedentary populations in supermarkets, train stations, and streets in Munich, Miskolc, and Malmö. Seemingly opposing discourses nevertheless share the attempt by different groups to appropriate and mobilise diverse border narratives in support of their political projects.

While in certain respects now arguably outdated, Jacques Derrida's seminal 1990 essay, The Other Heading: Memories, Responses, and Responsibilities, offers a reading of Europe's political futures via the lens of the border and highlights the dangers of our present conjuncture. At a colloquium on 'European cultural identity' held in Turin in 1990, Derrida 
delivered a now famous talk in which he argued that what defines any culture is that it is not identical to itself (Derrida, 1992: 9). This is not to say that culture does not have an identity, but that it does not identify with itself; in other words, culture or cultural identity is not pure or with a single origin, but always already a 'culture of the other' (Derrida, 1992: 10). No culture or political community, on this view, is an ipseic or sovereign entity, but is produced as a result of a series of multiple competing constitutive outsides; never pure, but always contaminated.

European cultural identity, which Derrida explores in his essay by reading philosophical texts, is caught between closure and openness. On the one hand, reflecting its geographical and material positioning as a headland or promontory, Europe has always self-associated with a 'spiritual heading' that has 'confused its [...] figure and its very place [...] with that of an advanced point'; indeed 'the final headland or point' (Derrida, 1992: 25). On the other hand, invoking the call of European memory and the uncertainty of its geographico-political borders to the south and east, Derrida posits the very idea of Europe as 'the opening onto a history for which the changing of the heading, the relation to the other heading or the other of the heading, is experienced as always possible' (Derrida, 1992: 17).

Against the backdrop of the dissolution of a series of spatial and temporal borders - the fall of the Berlin Wall, the break-up of the USSR, and the end of the Cold War - Derrida argued that Europe at his time of writing was characterised by 'the reopening and denaturalization of [...] monstrous partitions' (Derrida, 1992: 63). While he acknowledged the persistence of 'the crimes of xenophobia, racism, anti-Semitism, religious or nationalist fanaticism' as instances of a lack of openness to the Other, he also saw the 'taking place now' of an idea of Europe 'that consists precisely in not closing itself off in its own identity and in advancing itself in an exemplary way toward what it is not, toward the other heading or the heading of the other, indeed [...] toward the other of the heading [...] another border structure, another shore' (Derrida, 1992: 29).

Twenty-five years on, diverse events across multiple geographical sites retrospectively packaged as the '2015 Mediterranean migration crisis' have stimulated a series of policy and popular responses that suggest Europe's present trajectory is one characterised more by violent closures and a return to 'monstrous partitions' than the pursuit of the openings of the kind identified by Derrida. The crude reliance on fencing and barbed wire at the outer-edge of 
sovereign territorial states across Bulgaria, Hungary, and Macedonia - and the reintroduction of border controls in Denmark and Sweden - has given rise to the discourse of the 'return' of the border across Europe. Yet this discourse overlooks the ways in which European bordering practices did not disappear with the 1985 Schengen Agreement, but underwent a series of spatial and temporal displacements and deferrals in ever more complex and stealthy ways within and beyond the territory of European states.

Not as visible and yet no less violent in their effects are an array of technologies of border power that Europe relies upon in order to attempt to identify and control 'irregular' mobility at sites not traditionally understood to be 'borders' according to the modern geopolitical imagination. Some of these technologies, such as the outsourcing, off-shoring, and militarisation of bordering practices in the Mediterranean and in third states - and their exclusionary, violent, and often lethal effects on 'irregular’ migrant and refugee populations are by now well-known and documented in critical geographical literatures (Bialasiewicz, 2011). But it is also possible to identify the emergence of newer and less scrutinised attempts - increasingly justified under a humanitarian rubric - to striate space and produce 'knowable' and therefore 'governable' subjects.

To take one example, reflected in the opening testimony of a Somalian woman I met who used to work as a nurse, the medicalisation of European border security - based on short-term disease surveillance - creates new opportunities for knowledge production about otherwise unknown subjects and bodies deemed to be potentially 'risky' in diverse spaces from reception centres to hospitals. Bordering practices of this kind are of course intrinsically biopolitical modes of governance precisely in that they target the basic needs, vulnerabilities, and potentialities of 'irregular' populations in order to categorise them in different ways (Vaughan-Williams, 2015). Furthermore, the rise of compassionate or 'feel-good' borderwork - not unique to Europe, but increasingly a transnational phenomenon - permits therapeutic interventions that coopt the very logics of humanitarianism that those against the worst excesses of border-related violence have hitherto relied upon to mount their critique (Williams, 2015).

For these reasons, Derrida's concluding injunction in The Other Heading for Europe to respond to the duty of European memory to welcome foreigners 'not only to integrate them but to recognize their alterity' now appears somewhat quaint and a method of critique that is 
simply no longer up to the job - if it ever was (Derrida: 1992: 77). The known deaths of 3,771 'irregular' migrants and refugees in the Mediterranean Sea in 2015 alone (UNHCR 2015) - along with the rise of the far right across Europe, the normalisation of casual racism in many European cities, and populist incantations to 'reclaim our borders' - imply that Europe's current heading is one that no longer recognises even the conditional forms of hospitality that Derrida was ultimately critical of (Derrida 2002: 362).

Yet in reflecting on Europe's political futures now we also surely need to caution against the tautological dynamic whereby particular representations and mediations of Europe's present end up performatively shaping those futures. What Eurobarometer and other surveys fail to capture are the very effects that government and elite justifications for tougher border security based on homogenising notions of what 'the public wants' have on public opinion. Furthermore, if we look harder we find messier realities of hostility and hospitality and actually existing counter-narratives of the border - the powerful response to the circulation of the Alan Kurdi images, the persistence against the odds of Germany’s Willkommenskultur, local volunteer initiatives designed to support migrant and refugees with information and transportation, and alternative political economies that operate voucher systems for these groups, to take several prominent examples. In these practices we surely find traces of other border structures and shores that also have the potential to shape Europe's political futures.

\section{Europe, Borders and Uneven Geo-Economic Development}

Adrian Smith

Writing in 2015 in the context of the so-called European migration and refugee "crisis”, Étienne Balibar (2015) argued that "we have now entered a new era and that terms such as 'migrations', 'borders', 'population' along with the political categories built upon them have changed their meanings. Hence, we cannot use them as we have so far. On this [Balibar went on] ... we can say that Europe will either be realized by revolutionizing its vision of the world and its societal choices or it will be destroyed by denying realities and by holding onto the fetishes of the past”. Two years on, these comments seem even more apposite in the context of the deepening migration crisis, the U.K. referendum outcome to leave the European Union, and the enduring economic crisis in parts of the Eurozone and beyond. In this intervention I aim to address this question of the politics of Europe, and to reflect on its 
inter-relations with borders and uneven geo-economic development. I do so by reflecting on some of Balibar's writing on Europe and politics, and from my own experience over the last 25 years of working on the economic geographies of European integration and the "Eastern" and "Southern" questions, and having been engaged for several years in the editing of European Urban and Regional Studies, a journal dedicated to pan-European and progressive scholarship on Europe's uneven development. I do not focus on European borders “just” in the geo-political sense, but borders seen as a profound intermingling of the geo-political and the geo-economic (see also Smith 2013, 2015). Borders as the articulation, if you will, of the state and economy, of politics and markets and uneven development across border spaces as always a socially-produced, political question (see Hudson 1989).

My argument is that we see today a complex interweaving of continuing uneven development and marginalisation; post-crisis divergence, especially in the form of the economic and employment crisis in the South, and the continuing profound national and sub-national levels of uneven development (see also Smith 2013, Andreotti and Mingione 2016, Gialis and Leontidou 2016, Vaiou 2016, Hudson 2017). This is taking place at a time of the reestablishment and re-working of new external and internal borders involving fundamental forms of differential integration into the heartlands of the European Union (Casas-Cortes et al 2013, 2016, Smith 2015). When this is combined with a tendency towards a more introverted politics looking away from European solidarity we have a very toxic mix. This is a mix, I argue, that requires - perhaps now more than ever - that progressive intellectual voices be heard and shape the debate.

In these comments I explore these articulations of Europe, borders and uneven development in three steps. The first is to consider the question of the externalisation and differential inclusion into European border spaces that we see today. The second is to consider what the U.K.'s referendum on membership of the European Union might tell us. The third concerns what responsibility we have as intellectuals in Europe today.

The EU's southern border space has, for a long time, been one of stark uneven economic development between both shores of the Mediterranean (Smith 2015). But it is today following the Eurozone crisis and the Arab Spring revolutions - the site of both deep economic crisis and marginalisation in southern Europe and deepening attempts by the European Union to externalise further its modes of economic and border governance, most 
notably through the negotiations of Deep and Comprehensive Free Trade Agreements (the DCFTAs) with Tunisia and Morocco (now stalled, with the latter). This process of externalisation of economic governance that we currently see - not only in North Africa but also in other engagements with neighbouring states in the east of Europe (Ukraine, Moldova and Georgia, for example) and elsewhere - is part and parcel of the attempt to re-align, following Mezzadra and Neilson (2013), the politico-juridical boundaries of the EU macroregional state with those of capital and markets (Smith 2015). Europe’s borders, then, are not just political moments, not just about bordering practices, but represent the fundamental reordering of the spaces of the state with the spaces of capital, both externally through the panoply of international association and trade agreements and internally via the Single Market.

Indeed, there is a parallel process in play in the east of Europe - one involving the multiplication of new border spaces (the EU's Eastern Partnership for example) in the context of Russia's interests in the border zone between the EU and the former Soviet Union. Balibar (2015) argued that "Europe forms a space within which borders multiply and move incessantly, 'chased' from one spot to the other by an unreachable imperative of closure, which leads to its 'governance', resembling a permanent state of emergency”. Rather than a language of closure, bordering processes are rather those of differential inclusion and exclusion (see Smith 2002, Pickles and Smith 2016). Bordering practices in Europe are - of course - about closure. But they are not just that. They are also about opening in controlled and highly differentiated terms the geo-economic and geopolitical spaces both within the EU and in its partner and neighbouring countries; whether that is through staged visa liberalisation, or differential access for refugees, or through differentiated market access arrangements for different product segments (e.g. agricultural goods), or through the dissemination of technical and sanitary and phytosanitary standards in industrial and agricultural production systems which differentiate between the capacity of large and small, capital and non-capital rich producers to engage with new regulatory requirements to ensure market access to the Single Market (Smith 2015). Each of these is a simultaneously political and economic question around differential inclusion as the European Union seeks to incessantly externalise its borders.

Balibar, in his earlier "We, the People of Europe?”, and in the context of his treatment of the multiple identity politics of "Europe”, insisted on a representation of borders as "mobile 
“overlapping” zones ... rather than ... juxtapositions of monolithic entities” (Balibar 2004: 5). This sense of mobile overlapping zones is helpful in thinking about the second focus for my comments; the U.K.'s referendum on membership of the European Union and that of Brexit. It is obvious to say, but given the profundity of the outcome of the referendum, nevertheless important to state clearly, that the UK's exit from the EU will (re-)create new borders within Europe, especially if - given the inability of the UK government to articulate a clear position on what kind of trading relationship it wishes to put in place with the EU there is resort to WTO rules of engagement on the basis of what will most likely have to be newly negotiated most favoured nation principles, and a stronger regulation of migration flows for specific categories of skilled migrant workers. The open question remains what forms of differentiated borders will emerge in the context of these new borders; who will gain access and mobility; what tariff levels will apply; what forms of standards regulation on products will be deployed, and so on. However, here I want to focus less on the consequences of Brexit and more on how we might understand how and why the referendum ended up with the outcome that it did, with all its differentiated geography of region, locale, class, age, and gender underpinning the voting outcomes, and while recalling the fact that the vote to leave was a vote of $51.9 \%$ of $72.2 \%$ of the electorate. Brexit, it seems, resulted from the intersection of two “overlapping zones”, to coin Balibar’s term. The first voted for Brexit based on an understanding of the fetishes of the past, a perceived return to a mythical golden era of national autonomy, misplaced notions of democratic governance and parliamentary sovereignty - which is likely to be more about a rescaling of the power of big business over politics. This is what some called the "little Englanders", but the motivations - and this is the important point - are seen articulated in different but equally profound and potentially important ways elsewhere in Europe in 2017 with elections in Germany and France. This is not then just a British (or English) question, although - of course - it is that as well. It is a wider question about understanding the limits to, in the current framework of EU integration and politics, the scaling up of democratic possibilities across Europe.

The second of the overlapping zones is that of the marginalised; those who felt and were excluded from the gains of economic globalisation and European integration. In his 1999 essay “Droit de cité or Apartheid?”, Balibar wrote in revealing terms for the current context that "it is difficult to conceive of supranational institutions being recognized as legitimate if they do not procure for the individuals they bring together an at least equal (and in fact greater) level of security [both politically and economically I would add] and degree of 
democratic participation than existed in the framework of traditional nation-states, even when weakened by the crisis of governability and mass unemployment” (2003: 43). In the minds of too many of the UK's citizens - not least because of the failure of the mainstream British political classes on both right and left to ever make the case for Europe - the democratic deficit and economic exclusions were seen to be too great. It was a crisis resulting from a particular kind of hegemonic ideology, combined with parts of the populace experiencing economic marginalisation and seeing few of the gains from liberalised market and global integration (Goodwin and Heath 2016, Hudson 2017).

The third issue I address concerns what responsibility we have as intellectuals and geographers in Europe today. We do need to talk about Europe and Brexit; not for parochial reasons or to celebrate the outcome of the referendum, but because it raises fundamental questions across Europe for what it means to be European and what kind of Europe we want to be citizens of and progressive geographers in. Balibar's call for a progressive, more radical conception of a transnational political counter-culture is more than ever required today. Understanding and intervening on the intertwining of "strategy, power, agency and subjectivity” in Europe today, as Balibar put it (2004: 220), is needed perhaps more now than ever. Writing about Europe after communism in the early 1990s, Balibar raised a question which remains fundamental to today’s conjuncture: “The true question [he argued] is whether we ... are seeking to invent new forms of European solidarity, of communication between peoples with the aim of formulating common objectives, or whether we will continue to treat the problems of “European equilibrium” by means of force, market logic, propaganda, and formal diplomacy” (Balibar 2004: 99). These are the kinds of questions that we must continue to ask at a time when we need to hold onto a sense of what it means to be progressive Europeans, citizens of Europe (if not the European Union), and critical scholars. We need to find new voices to embrace the progressive internationalism that Europe portends.

\section{Acknowledgements}

These interventions are based on presentations made at a Political Geography organised panel session on “Europe’s Political Futures”, held at the Royal Geographical Society (with the Institute of British Geographers), Annual International Conference, London, in September, 2016. We are grateful to the audience for their constructive questions. 


\section{References}

Abrams, P. (1988). Notes on the Difficulty of Studying the State (1977).Journal of historical sociology, 1(1), 58-89.

Andreotti, A. and Mingione, E. (2016) "Local welfare systems in Europe and the economic crisis”, European Urban and Regional Studies, 23 (3): 252-266.

Bachmann, V. and Sidaway, J. D. (2009) Zivilmacht Europa: a critical geopolitics of the European Union as a global power. Transactions of the Institute of British Geographers 34: 94-109

Balibar, E. (2004) We, The People of Europe? Reflections on Transnational Citizenship, Princeton: Princeton University Press.

Balibar, E. (2015) Borderland Europe and the challenge of migration, OpenDemocacy, 8 September 2015. Available at: https://www.opendemocracy.net/can-europe-makeit/etienne-balibar/borderland-europe-and-challenge-of-migration. Accessed on 19 July 2016.

Bialasiewicz, L. (2008) The Uncertain State(s) of Europe? European Urban and Regional Studies 15(1): 71-82.

Bialasiewicz L (ed) (2011) Europe and the World: EU Geopolitics and the Transformation of European Space. Hampshire and Berlington, VT: Ashgate.

Bialasiewicz, L., Dahlman, C., Matteo Apuzzo, G., Ciută, F., Jones, A., Rumford, C., Wodak, R., Anderson, J., and Ingram ,A. (2009) Interventions in the new political geographies of the European 'neighborhood'. Political Geography 28: 79-89

Boyle, M., \& Kobayashi, A. (2015). In the face of epistemic injustices?: on the meaning of people-led war crimes tribunals. Environment and Planning D: Society and Space, 33(4), 697-713.

Carr, M. (2012) Fortress Europe: Dispatches from a gated continent, C. Hurst \& Co., London

Casas-Cortes, M., Cobarrubias, C. and Pickles, J. (2013) "Re-bordering the neighbourhood: Europe’s emerging geographies of non-accession integration”, European Urban and Regional Studies, 20 (1): 37-58.

Casas-Cortes, M., Cobarrubias, C. and Pickles, J. (2016) “'Good neighbours make good fences': Seahorse operations, border externalization and extra-territoriality”, European Urban and Regional Studies, 23 (3): 231-251. 
Chakrabarty, D. (2009). Provincializing Europe: Postcolonial thought and historical difference. Princeton: Princeton University Press.

Clark, J. and Jones, A. (2008) The spatialities of Europeanisation: territory, government and power in 'EUrope'. Transactions of the Institute of British Geographers 33: 300-18

Collyer, M. (2015) Conditions and Risks of Mixed Migration in North East Africa, MHub (North Africa Mixed Migration Task Force), www.mixedmigrationhub.org/resources/mmtf-noah-research

Comaroff, J. L. and Comaroff, J. (2006) "Law and Disorder in the Postcolony: An Introduction.” In Comaroff, J. L. and Comaroff, J. (Eds.) Law and Disorder in the Postcolony. Chicago: University of Chicago Press, pp. 1-56.

Crawley, H., Düvell, F., Jones, K., McMahon, S. and Sigona, N. (2016) 'Destination Europe? Understanding the dynamics and drivers of Mediterranean migration in 2015', MEDMIG Final Report, http://www.medmig.info/research-brief-destination-europe/

Delanty, G. and Rumford, D. (2005). Rethinking Europe. Abingdon: Routledge.

Derrida, J. (2002) Acts of Religion. Ed G. Anidjar. New York and London: Routledge.

Derrida, J. (1992) The Other Heading: Reflections on Today’s Europe. Trans P-A. Brault and M. Naas. Bloomington and Indianapolis: Indiana University Press.

Engelen, E., Hendrikse, R., Mamadouh, V., \& Sidaway, J. D. (2011). Turmoil in Euroland: the geopolitics of a suboptimal currency area? Environment and Planning D, 29(4), 571-583.

EU Commission (2016) 'Enhancing security in a world of mobility', available online at: http://ec.europa.eu/justice/citizen/document/files/com_2016_602_enhancing_secur ity_en.pdf (accessed 30 December 2016).

European Commission (2016) 'Turkey: Refugee Crisis', ECHO Factsheet http://ec.europa.eu/echo/files/aid/countries/factsheets/turkey_syrian_crisis_ en.pdf

Geddes, A. and Scholten, A. (2016) The Politics of Migration and Immigration in Europe ( $2^{\text {nd }}$ edition), Sage

Gialis, S. and Leontidou, L. (2016) “Antinomies of flexibilization and atypical employment in Mediterranean Europe: Greek, Italian and Spanish regions during the crisis”, European Urban and Regional Studies, 23 (4): 716-733.

Goodwin, M. and Heath, O. (2016) "Brexit vote explained: poverty, low skills and lack of opportunities”, Joseph Rowntree Foundation. Available at: https://www.jrf.org.uk/report/brexit-vote-explained-poverty-low-skills-and-lack- 
opportunities Accessed on 3 January 2017.

Howden, D. (2016) 'The manufacture of hatred: scapegoating refugees in Central Europe', Refugee Deeply https://www.newsdeeply.com/refugees/articles/2016/12/14/themanufacture-of-hatred-scapegoating-refugees-in-central-europe

Hudson, R. (1989) Wrecking a Region: State Policies, Party Politics, and Regional Change in North East England, London: Pion.

Hudson, R. (2017) "Facing forwards, looking backwards: Coming to terms with continuing uneven development in Europe”, European Urban and Regional Studies

Hungarian Government (2015) 'National consultation on immigration to begin', 24 ${ }^{\text {th }}$ April 2015 http://www.kormany.hu/en/prime-minister-s-office/news/national-consultationon-immigration-to-begin

IOM (2016) Mixed Migration: Flows in the Mediterranean and Beyond: Compilation of Available Data and Information 2015. Geneva: International Organization for Migration

(GMDAC), http://doe.iom.int/docs/Flows\%20Compilation\%202015\%200verview.pd $\underline{f}$

Jeffrey, A. (2008). Contesting Europe: the politics of Bosnian integration into European structures. Environment and Planning D: Society and Space, 26(3), 428-443.

Jeffrey, A., \& Jakala, M. (2015). Using courts to build states: The competing spaces of citizenship in transitional justice programmes. Political Geography, 47, 43-52.

Jones, C. (2016). Lawfare and the juridification of late modern war, Progress in Human Geography, 40(2), 221-239.

Jones, E. (2015) 'Getting the Story Right: How You Should Choose Between Different Interpretations of the European Crisis (and Why You Should Care)'. Journal of European Integration 37 (7), pp. 817-832.

Keller, H., Fischer, A., \& Kühne, D. (2010). Debating the future of the European Court of Human Rights after the Interlaken Conference: two innovative proposals. European Journal of International Law, 21(4), 1025-1048.

Korket, U., Bucken-Knapp, G., McGarry, A., Hinnfors, J. and Drake, H. (eds) The Discourse and Politics of Migration in Europe, Palgrave McMillan

Kristeva, J. (2000). Crisis of the European subject. New York: Other Press.

Kuus, M. (2016) 'Transnational Diplomacy in Europe: What is Transcended and How? in Dittmer J. and McConnell F. (Eds) Diplomatic Cultures and International Politics: Translations, Spaces and Alternatives, pp. 41-58. Routledge, London. 
Kuus, M. (2014) Geopolitics and Expertise: Knowledge and Authority in European Diplomacy. Chichester: Wiley Blackwell.

Megoran, N. (2008). Militarism, realism, just war, or nonviolence? Critical geopolitics and the problem of normativity. Geopolitics, 13(3), 473-497.

Merritt, G. (2016) 'The refugee crisis: Europe needs more migrants not fewer’, Europe’s World http://europesworld.org/2015/10/26/the-refugee-crisis-europe-needs-moremigrants-not-fewer

Mezzadra, S. and Neilson, B. (2013) Border as Method, or, The Multiplication of Labor, Durham, NC: Duke University Press.

Murphy, A.B. (2013) Trapped in the Logic of the Modern State System? European Integration in the Wake of the Financial Crisis. Geopolitics 18(3): 705-723.

Petrakos, G., Tsiapa, M., Kallioras, D. (2016). Regional inequalities in the European Neighborhood Policy countries: the effects of growth and integration. Environment and Planning C 34(4), 698-716.

Pickles, J. and Smith, A. (2016) Articulations of Capital: Global Production Networks and Regional Transformations, Oxford: Wiley.

Reid-Henry, S., Elden, S., McConnell, F., Murphy, A. B., Newman, D. and Agnew, J. (2010) 'Geopolitics Roundtable: New Thinking on Territory, Sovereignty and Power'. Geopolitics. 15(4), pp. 752-784.

Rogers, R. (1992) 'The politics of migration in the contemporary world', International Migration 30(1), 33-55

Schabas W. (2012). Unimaginable Atrocities: Justice, Politics and Rights at the War Crimes Tribunals. Oxford: Oxford University Press.

Schepelle, K.L. (2015) 'The Hungary games: how Budapest its migration obligations', Politico 24 August 2016 http://www.politico.eu/article/hungary-games-migrationrefugees-asylum-crisis/

Scott, J. W., and van Houtum, H. (2009) Guest Editorial: Reflections on EU territoriality and the 'bordering' of Europe. Political Geography 28: 271-3

Smith, A. (2002) "Imagining geographies of the 'new Europe': geo-economic power and the new European architecture of integration”, Political Geography, 21: 647-70.

Smith, A. (2013) "Europe and an inter-dependent world: uneven geo-economic and geopolitical developments”, European Urban and Regional Studies, 20 (1): 3-13.

Smith, A. (2015) "Macro-regional integration, the frontiers of capital and the externalisation of economic governance”, Transactions of the Institute of British Geographers 40 (4): 
507-522.

Spijkerboer, T. (2016) ‘Europe’s refugee crisis: a perfect storm’, www.law.ox.ac.uk/researchsubject-groups/centre-criminology/centrebordercriminologies/blog/2016/02/europe’s-refugee

Thulin, E. and Vilhelmson, B. (2015) 'The internet and desire to move: the role of virtual practices in the inspiration phase of migration', Tijdschrift voor Economische en Sociale Geografie 107(3), 257-269

UNCHR (2015) Refugees/migrants emergency response - Mediterranean. Available at: http://www.data.unhcr.org/mediterranean/regional.php (accessed 2 January 2016).

UNHCR (2015) Mid Year Trends 2015, Geneva: www.unhcr.org/56701b969.html

Vaiou, D. (2016) “Tracing aspects of the Greek crisis in Athens: putting women in the picture”, European Urban and Regional Studies, 23 (3): 220-230.

Van Dyke, J.M. (2005) 'An analysis of the Aegean disputes under international law'. Ocean Development and International Law 36(1), 63-117

Vassalotti, J. (2011) 'Rough seas: the Greek-Turkish Aegean Sea dispute and ideas for resolution', Loyola of Los Angeles International and Comparative Law Review 33(3): 387-399, available at http://digitalcommons.lmu.edu/ilr/vol33/iss3/2

Vaughan-Williams, N. (2015) Europe's Border Crisis: Biopolitical Security and Beyond. Oxford and New York: Oxford University Press.

Walker, R. B. J. (2000) 'Europe is Not Where It Is Supposed to Be’, in M. Kelstrup and M.C. Williams, eds. International Relations Theory and the Politics of European Integration: Power, Security and Community. London and New York: Routledge, pp. 14-32.

Williams, J. (2015) From humanitarian exceptionalism to contingent care: care and enforcement at the humanitarian border. Political Geography 47: 11-20.

\footnotetext{
i 'Unravelling the Mediterranean Migration Crisis' (MEDMIG) was supported by the Economic and Social Research Council [grant number ES/N013506/01]. More at www.medmig.info

${ }^{\text {ii }}$ Research undertaken as part of Leverhulme Trust funded project 'European Narratives of Border Security and Insecurity’ (PLP-2015-081).
} 
iii Extract from fieldwork interview for ESRC funded project 'Crossing the Mediterranean Sea By Boat: Mapping and Documenting Journeys and Experiences’ (ES/N013646/1). 